\title{
The genetic diagnose and preventive thyroidectomy in a child with MEN-2A
}

\section{Badania genetyczne i tyreoidektomia prewencyjna u dziecka z MEN-2A}

\author{
${ }^{1}$ Anna Rakus-Kwiatosz, 'Iwona Ben-Skowronek, ${ }^{1}$ Stanisław Połtorak, ${ }^{2}$ Anna Czarniecka \\ 1'Department of Paediatric Endocrinology and Diabetology of Medical University of Lublin \\ 2Department of Oncological and Reconstructive Surgery, Center of Oncology, Institute of Oncology Memorial Maria Sklodowska-Curie in Gliwice, Gliwice \\ Corresponding author: $\quad$ Anna Rakus-Kwiatosz MD, Department of Paediatric Endocrinology and Diabetology, Medical University of Lublin, \\ Poland, tel: 48-81-718-54-40; e-mail: akwiatosz@interia.pl \\ Ben-Skowronek Iwona MD,PhD ass. Prof, Department of Paediatric Endocrinology and Diabetology, \\ Medical University in Lublin tel: 48-81-718-54-40; e-mail: skowroneki@interia.pl
}

Key words: MEN 2A, medullary thyroid cancer

Slowa kluczowe: MEN 2A, rak rdzeniasty tarczycy

\section{ABSTRACT/STRESZCZENIE}

Introduction. Medullary Thyroid Cancer (MTC) is the most consistent feature of the MEN 2A syndrome. Due to active screening the number of children diagnosed with MEN 2 is probably going to increase. Case report. The 7-year-old girl diagnosed with high risk MEN 2A (ATA-C) mutation (MEN 2A diagnosed in the mother) undergone prophylactic thyroidectomy, on histopatological examination bifocal MTC and several foci of C-cell hyperplasia were detected. The therapy with 1-thyroxin was started. The patient stays in observation because of the possibility of the other components of MEN 2A development. Conclusion. The preventive thyreoidectomy in children diagnosed with MEN 2A can protect them against inevitable metastatic disease. Pediatr. Endocrinol. 13/2014;4(49):53-56.

Wstęp. Rak rdzeniasty tarczycy (MTC) jest najczęstszym objawem zespołu MEN 2A. Liczba dzieci z zespołem MEN 2A rośnie ze względu na aktywnie prowadzone badania przesiewowe u dzieci rodziców z tym zespołem. Opis przypadku. 7-letnia dziewczynka $\mathrm{z}$ wysokim ryzykiem rozwoju MEN 2A (ATA-C) (MEN 2A zdiagnozowany u matki) została poddana prewencyjnej tyreoidektomii. W badaniu histopatologicznym wykryto dwa ogniska raka rdzeniastego tarczycy. Rozpoczęto substytucyjne leczenie 1-tyroksyną. Pacjentka pozostaje pod obserwacją ze względu na możliwość ujawnienia się pozostałych składowych zespołu MEN 2A. Wniosek. Prewencyjna tyreoidektomia u dzieci z MEN 2A może zapobiec rozwojowi przerzutów raka rdzeniastego tarczycy. Endokrynol. Ped. 13/2014;4(49):53-56. 


\section{Introduction}

Multiple endocrine neoplasia type 2A (MEN 2A) is an autosomal dominant disorder caused by germline mutations of the RET (Rearranged during Transfection) proto-oncogene [1]. It is characterized by the triad of medullary thyroid cancer (MTC), pheochromocytoma and parathyroid hyperplasia. DNA analysis enables unambiguous detection of the RET mutation carriers. MTC is the most consistent feature of the syndrome, usually the first clinical manifestation and the principal cause of mortality[1]. Therefore, the availability of genetic analysis in identifying presymptomatic patients revolutionized the management of children - kindred members of families carrying the mutations [2]. Currently, due to active screening the number of children diagnosed with MEN 2 in their early childhood is probably going to increase.

\section{Case report}

A 7-year-old female with known MEN 2A after thyroidectomy presented to our Dept. Endocrinology and Diabetology to have control tests performed. The patient was identified through familiar screening due to a positive maternal history of MEN 2A. The mother had been treated for nodular goiter - clinically apparent medullary thyroid carcinoma, genetic testing revealed that she was a carrier of RET mutation. She had also undergone bilateral adrenalectomy for phaeochromocytoma.

The patient herself was diagnosed with $\mathrm{C} 634 \mathrm{~F}$ mutation. The analysis was performed by PCR amplification followed by direct sequencing for exon 11 of the RET proto-oncogene, the result of the screening was confirmed on a duplicate DNA.

Because of high risk mutation, although preoperative basal serum calcitonin level was normal and a normal thyroid gland was observed under ultrasonography, the girl had undergone prophylactic total thyroidectomy in a few months after the genetic diagnosis. On histopatological examination bifocal MTC $1,5 \mathrm{~mm}$ in diameter was found and surrounding several foci of C-cell hyperplasia were detected $(\mathrm{pT} 1 \mathrm{a}(\mathrm{m}))$. Directly after the surgery the substitution of L-thyroxine was started. The patient was maintained on 1- thyroxine replacement therapy $88 \mathrm{ug} /$ day without additional complaints. Basal serum calcitonin was normal in 5 months after surgery, no signs of altered parathyroid function, as they were probably preserved, or catecholamine overproduction were found until now.

Informed consent from a mother to present the case was obtained.

\section{Discussion}

Most pediatric patients with MEN2 are identified by genetic testing due to positive family history[3]. MEN 2A is inherited in autosomal dominant fashion with very high penetrance [1]. When a positive mutation is detected, the carrier must be supported regarding the potential risk for their relatives. As the mother of our patient was diagnosed with germline mutation in RET proto-onkogene, the girl had a $50 \%$ chance of inheriting the mutation - and if positive $-100 \%$ lifetime risk of developing cancer syndrome. The progression from c-cell hyperplasia to MCT and eventually metastatic spread is age related $[1,4]$. Thus, the genetic screening should be carried out in young children as soon as a potential disease inheritance is suspected.

The expression of MEN varies between different codon mutations [1]. The family harboured codon 634 (exon 11) mutation which is highly associated with the classical phenotype of MEN2A: MCT, pheochromocytoma and hyperparathyroidism. MTC is typically the first clinical manifestation of MEN2A, as it was in the case reported here. It is less common for MEN to be diagnosed after identifying two other elements of the syndrome: pheochromocytoma [5] or hyperparathyroidism [6], individually or simultaneously.

There is a genotype-phenotype correlation the aggressiveness of the MTC varies depending on specific RET mutation $[3,4]$. Recent American Thyroid Association (ATA) guideline stratifies patients according to present mutations into 4 risk groups, from the lowest (A) to the highest (D) [7]. The greatest risk (ATA-D) is connected with the presence of alleles typical of MEN 2B, but among MEN 2A variants, most of codon 634 mutations appear to have the highest penetrance, resulting in early onset of MCT and frequent development of hyperparathyroidism and pheochromocytoma (ATA-C) [7].

Systemic adjuvant therapy options are limited [3], hence initial surgical management is essential as the only curative treatment [2]. The removal of the organ can be considered since the genetic identification is unambiguous, thyroid function can be replaced by lifelong 1-thyroxine supplementation and 
elective thyroidectomy is associated with minimal morbidity [2].

The clinical challenge lies in determining the timing and extent of surgical intervention. Current guidelines for the management of patients with ATA-C (the described patient) mutations recommend total thyroidectomy by the age of 5. The girl was screened at the age of 7 and the clinical manifestation of the disease could not be demonstrated.
However, on histological examination C-cell hyperplasia and MTC foci were identified. The surgery was rather 'preclinical' than 'prophylactic' as the removed organ was not totally free of the disease. Pathologist findings verify that $\mathrm{C}$-cell hyperplasia and /or medullary microcarcinoma is frequently detected in postoperative specimens from thyroidectomies in at-risk patients [8]. Because MTC was diagnosed as early as at the age of 7 , it is yet an-

Germline RET mutation positive and normal thyroid exam:

- obtain preoperative serum calcium. Treat hyperparathyroidism with 4 gland resection and autograft to heterotopic site, or subtotal parathyroidectomy. Consider cryopreservation.

- PHEO preoperative screening should begin by age 8 years for MEN 2B and mutated RET codons 634 and 630; otherwise by age 20 years for other $R E T$ mutations.

- obtain serum calcitonin in MEN 2B if age $>6$ months, and MEN 2A or FMTC if age $>3$ years.

- obtain skilled neck US (to include the superior mediastinum and central and lateral neck compartments) in all MEN 2B patients, and in MEN 2A/FMTC if age $>3-5$ years.

$$
\downarrow
$$

- No lymph node metastases

- all thyroid nodules $<5 \mathrm{~mm}$ and

- calcitonin $<40 \mathrm{pg} / \mathrm{mL}$

diagnosis and therapy of

clinically apparent disease

$\rightarrow \mathrm{NO} \rightarrow$

$\downarrow$ YES

\begin{tabular}{|c|c|c|}
\hline MEN 2A or FMTC & \multicolumn{2}{|l|}{ MEN 2B mutation (ATA-D) } \\
\hline $\begin{array}{l}\text { - ATA-C (634 mutations): prophylactic thyroidectomy } \\
\text { before age } 5 \text { years. } \\
\text { - ATA-A and ATA-B: prophylactic surgery may } \\
\text { be delayed beyond age } 5 \text { years in the setting of a } \\
\text { normal annual basal } \pm \text { stimulated serum calcitonin, } \\
\text { normal annual neck US, less aggressive MTC family } \\
\text { history, and family preference } \\
\text { - For higher risk mutations (ATA-B), consider } \\
\text { treatment before age } 5 \text { years regardless of other } \\
\text { factors. }\end{array}$ & $\begin{array}{l}\text { - Age 0-1 year old } \\
\text { - Insufficient data to } \\
\text { recommend routine } \\
\text { prophylactic level VI } \\
\text { compartment dissection }\end{array}$ & $\begin{array}{l}\text { - Age >1 year old include } \\
\text { prophylactic level VI } \\
\text { compartment dissection }\end{array}$ \\
\hline
\end{tabular}

$\downarrow \quad \downarrow \quad \downarrow$

- Surgery in an experienced tertiary care setting

- Total thyroidectomy

- Level VI compartmental dissection if clinical lymph node metastases

- Give high priority to preserve parathyroid function. Parathyroid glands resected or devascularized should be autografted in the neck in RET-negative, MEN 2B, and FMTC patients, while MEN 2A glands should be auto graphed to a heterotopic site.

- Lateral neck compartmental dissection of image- or biopsy-positive compartments

Fig. 1. Initial diagnosis and therapy of pre-clinical disease (Based on ATA medullary thyroid cancer guideline 2009 [7]) 
other example confirming that thyroidectomy is advocated before that age in this type gene carriers. The case also indicates that the diagnosis of MTC cannot always be excluded by a normal ultrasound examination of thyroid gland [9] or preoperative calcitonin level in codon 634 mutations.

There are many factors affecting the outcome of the treatment: specific RET codon mutation, the preoperative calcitonin level, age at the time of thyroidectomy, histological status and tumor stage if present [10]. In patients such as the described one with disease restricted to the thyroid gland and without nodal involvement, the risk of recurrence and mortality is very low $[2,8]$. Nevertheless, according to current approaches for the diagnosis and management of the MEN 2A families, the girl should have been operated on earlier. Dutch nationwide study suggests that the majority of patients until 2006 were not operated on at the recommended age [4]. But it is claimed that prophylactic thyroidectomy beyond the advised age is associated with persistent or recurrent MTC [4].

Each patient demands careful postoperative surveillance. Thyroid hormone replacement is essen- tial, but without TSH suppression as MTC cells are not TSH-dependant. To enable normal development, follow-ups should be done at regular intervals. The patient has already reached the age of 8 , therefore, according to ATA guidelines has been screened for pheochromocytoma. As the parathyroids were not removed, their function should also be monitored [figure].

\section{Conclusions}

With the advent of genetic screening, prophylactic thyroidectomies are increasingly performed on younger patients as a life-saving treatment. Therefore, although still rarely, paediatric endocrinologists are more commonly encountering these patients in routine practice and should monitor any potential other endocrine system cancer development.

Acknowledgments: podziękowania dla pracowników Centrum Onkologii w Gliwicach za wykonanie badań genetycznych.

Funding: Grant of Medical University in Lublin

Competing interest: None.

\section{REFERENCES/PIŚMIENNICTWO}

[1] Boikos S.A., Stratakis C.A.: Molecular mechanisms of medullary thyroid carcinoma: current approaches in diagnosis and treatment. Histol Histopathol., 2008:23(1), 109-116.

[2] Skinner M.A., Moley J.A., Dilley W.G. et al.: Prophylactic thyroidectomy in multiple endocrine neoplasia type 2A. Jr. N. Engl. J. Med., 2005:15,353(11), 1105-1113.

[3] Roy M., Chen H., Sippel R.S.: Current understanding and management of medullary thyroid cancer. Oncologist, 2013:18(10), 1093-1100.

[4] Schreinemakers J.M., Vriens M.R., Valk G.D. et al.: Factors predicting outcome of total thyroidectomy in young patients with multiple endocrine neoplasia type 2: a nationwide long-term follow-up study. World J. Surg., 2010:34(4), 852-860.

[5] Rowland K.J., Chernock R.D., Moley J.F.: Pheochromocytoma in an 8-year-old patient with multiple endocrine neoplasia type 2A: implications for screening. J. Surg. Oncol., 2013:108(4), 203-206.

[6] Magalhães P.K., Antonini S.R., de Paula F.J. et al.: Primary hyperparathyroidism as the first clinical manifestation of multiple endocrine neoplasia type 2A in a 5-year-old child. Thyroid, 2011:21(5), 547-550.

[7] American Thyroid Association Guidelines Task Force. Medullary thyroid cancer: management guidelines of the American Thyroid Association. Thyroid, 2009:19, 565-612.

[8] Etit D., Faquin W.C., Gaz R. et al.: Histopathologic and clinical features of medullary microcarcinoma and C-cell hyperplasia in prophylactic thyroidectomies for medullary carcinoma: a study of 42 cases. Arch. Pathol. Lab. Med., 2008:132(11), 1767-1773.

[9] Morris L.F., Waguespack S.G., Edeiken-Monroe B.S. et al.: Ultrasonography should not guide the timing of thyroidectomy in pediatric patients diagnosed with multiple endocrine neoplasia syndrome 2A through genetic screening. Ann. Surg. Oncol., 2013:20(1), 53-59.

[10] Frank-Raue K., Buhr H., Dralle H. et al.: Long-term outcome in 46 gene carriers of hereditary medullary thyroid carcinoma after prophylactic thyroidectomy: impact of individual RET genotype. Eur. J. Endocrinol., 2006:155(2), 229-236. 